\title{
The Very Rev. William Paterson Paterson, D.D., LI.D.
}

By the sudden passing on January I0, 1939, of the Very Rev. Professor Paterson, Scotland has lost a highly gifted son and learning a brilliant luminary. Born at Skirling in $\mathrm{I} 860$, he received his early education at the parish school and the Royal High School, Edinburgh. A notable graduate in Arts and Divinity of the University of Edinburgh, he completed his theological studies at the Universities of Leipzig, Erlangen, and Berlin. From I 887 to 1894 he was parish minister of Crieff. In the latter year he was appointed to the Chair of Systematic Theology at the University of Aberdeen-an office which was then filled by examination (recently abolished), from which he emerged as the successful competitor. In 1903 he was elected to succeed Professor Flint, distinguished alike as theologian and philosophical historian. In 1916 he was appointed Chaplain to the King in Scotland, and three years later was elected Moderator of the General Assembly of the Church of Scotland. As Dean of the Faculty of Divinity, he took a leading part in the reorganisation of the Courses for the B.D. degree of the University of Edinburgh and in the inauguration of that of Ph.D. in Theology for the purpose of stimulating specialisation and research in theological study. His early reputation as a theologian is evinced by his appointment as Baird Lecturer in 1903-the lectures being subsequently published under the title The Rule of Faith. A still greater testimony to his reputation as a theologian was his selection as Gifford Lecturer at the University of Glasgow in 1923, the fruit of which appeared in his masterly work, The Nature of Religion. In I93 I he was invited to deliver the Sprunt Lectures at Richmond, Virginia, and four years later the Forman Lectures at Liverpool, while in 1912 he filled, by invitation, for six months the pulpit of the Scots Church at Melbourne. The far-flung eminence, to which these appointments testify, also brought him many academic honours. Edinburgh, St Andrews, and Trinity College, Dublin, conferred on him the Hon. D.D. degree; Edinburgh, Glasgow, and Pennsylvania that of LL.D.

Paterson was a man of keen, penetrative mind and of wide culture. His retentive memory enabled him to work with ease his wide knowledge into his lectures, books, sermons, and speeches. He was a lucid and effective teacher, who drew students from many lands to his classroom. 
The essentials of a subject were set forth with a rare precision, which shunned verbosity, and yet was never dull. His nimble mind was always working, point by point, towards a demonstration of the problems under discussion. He was likewise a telling speaker, in faculty and senate, on the public platform, and on social occasions. His ready wit lightened the subject when the occasion permitted. Like his culture, his interest and his activity took a wide sweep. He was an ardent sociologist and social worker. Witness his activity on behalf of the temperance movement and his collaboration with the Rev. Dr D. Watson of Glasgow in a volume on Social Evils and Problems. Many causes in behalf of human betterment could count on his energetic support in committee, on the platform, and in the press. In this wider sense his death is a grevious loss to his country as well as to the Church, while it has deprived his friends and colleagues of one whose rich personality and kindly tolerance ever attracted and endeared.

He was elected a Fellow in I9I8.

J. MACK. 